\title{
The role of schools in responding to the needs of immigrant and refugee children
}

\begin{abstract}
This paper explores the "crisis of connection" and the way in which the "empathy gap" has become manifest in the treatment of refugee children in schools, and in modern Western societies generally. Despite the fact that schools in the US have historically played a central role in integrating new immigrants into American society, schools are increasingly ill equipped and unprepared to respond adequately to the needs of the new wave of refugees and unaccompanied minors. Moreover, with growing hostility toward immigrants expressed by politicians, civic groups and the media, public willingness to assist schools in serving the newly arrived has eroded. This paper examines the role of schools in overcoming the rise in xenophobia and anti-immigrant hysteria by drawing attention to schools and districts that have responded with compassion, empathy and a willingness to develop creative solutions to address the critical needs of immigrant and refugee children. Drawing on research carried out at several such schools and through the analysis of several case studies, the paper shows how education can overcome xenophobia and hostility in schools by promoting trust, belonging, student voice, and building on recognition of "common interests" that transcend differences based on nationality and legal status.
\end{abstract}

Volume 3 Issue 5 - 2019

\author{
Pedro A Noguera \\ Professor of Education, University of California, USA
}

\author{
Correspondence: Pedro A Noguera, PhD, Distinguished \\ Professor of Education, Faculty Director, Center for the \\ Transformation of Schools, UCLA Graduate School of Education \\ \& Information Studies I04IG Moore Hall, Box 95152I, 405 \\ Hilgard Avenue, Los Angeles, CA 90095 \\ Email pnoguera@gseis.ucla.edu
}

Received: September 27, 2019 | Published: October 21, 2019

\section{Introduction: the crisis of connection}

Throughout the ages we have to rediscover that our community is not only made of the highly motivated competing individuals ...but that it includes fragile, vulnerable, suffering individuals who reveal to ourselves our own fragility, our own vulnerability... This fundamental discovery is at the heart of our humanity. - Xavier Le Pichon

We are in the midst of a global refugee crisis. According to the United Nations High Commissioner for Refugees (UNHCR 2017), there are presently 65.6 million individuals who have been forcibly displaced as a result of political persecution, conflict, violence and climate change. ${ }^{1}$ Global response to the refugee crisis has been impaired by the rise in nationalist governments in Western nations and a growing "crisis of connection" that has limited our inability to overcome and transcend differences based upon nationality, race, religion, social class and political ideology. Increasingly, our ability to act affirmatively on common human interests are thwarted by an "empathy gap"; a condition that obstructs our ability to pursue our common interests as human beings and to ensure our collective need for peace, security, food, water, shelter and environmental stability. The crisis of connection exacerbates other problems such as our ability to prevent war, to combat terrorism and violence, and to counter poverty, hunger and disease. Because it reinforces xenophobia and nationalism, the crisis of connection produces a tolerance and indifference toward suffering and normalizes increasingly common forms of brutality and suffering.

Signs of the crisis of connection are particularly evident in the international response to the global refugee crisis. As millions of people are displaced from their homes and forced in many cases to risk their lives as they attempt to flee war, hunger and violence, a yawning empathy gap acts as a formidable obstruction to the development of humane and creative responses to suffering. According the United
Nations Refugee Council as many as sixty five million people throughout the world have been forcibly displaced from their homes. ${ }^{1}$ If they manage to find refuge in another nation, many of refugees and undocumented immigrants, often end up trapped in modern forms of slavery, subjected to a trade and form of bondage now referred to as human trafficking, while many others languish indefinitely in refugee camps. The tepid, ineffectual response to the global refugee crisis is reinforced and exacerbated by our acceptance of grotesque inequalities in wealth and access to resources; an imbalance that drives at least some of the refugee crisis, and often threatens the quality of life in places where the displaced wait to be settled.

The crisis of connection may not be the cause of the current refugee crisis but it is certainly a factor that has paralyzed politicians from reacting creatively and effectively to the enormous challenges we face. To the degree that war and violence is accepted as "normal" or "inevitable" in certain communities or parts of the world, to the degree that the signs of global warming are ignored because they are felt most directly in remote corners of the Pacific or South America, or to the degree that we learn to tolerate large numbers of people drowning after the woefully inadequate vessels they attempt to travel upon capsize, it becomes clear that the crisis of connection is exacting deadly consequences. In the United States we long ago learned to tolerate millions of mentally ill people living on our streets or filling our nation's prisons. Under the new Trump administration there is now a question of whether Americans will turn their backs entirely on the refugees who seek asylum on US territory. Fear and indifference are often at the core of the crisis of connection, and it is becoming increasingly clear that they may serve as the fuel and provide the rationale for a new immigration policy.

The crisis of connection deludes us into believing that the problems of unaccompanied minors that have arrived from Central America in recent years is not "ours". It lulls us into believing that 
if we didn't cause these young people to leave their homes and to risk their lives to enter the US, then we, the safe and unaffected, are not responsible for addressing it. We treat the gang violence of El Salvador, Honduras and Guatemala as "their" problem, even though the gangs that terrorize impoverished barrios and towns originated on the streets of Los Angles. Why worry about refugees unless they move into our neighborhoods? Why worry about war in Africa or the Middle East unless one of "terrorists" comes to our community and one of our loved ones is shot? Why not build a wall and demand that Mexico pay for it if we see the world not as a unitary whole but as one with borders that divide and separate?

There is a logic that drives the crisis of connection and it is evident in the US response to the international refugee crisis. It was one of the factors that prompted nearly half of the nation's voters to elect Donald Trump. ${ }^{1}$ Obviously, many of them resonated with his call to ban Muslims from entering the country and to keep the outsiders the terrorists, the rapists, the foreigners taking "our jobs", out. Wise actions and policies to manage immigration and respond humanely to the needs of the millions of undocumented people are difficult if not impossible to enact when large portions of the population resent, fear, feel disconnected and are unable to empathize with the suffering of others. Indifference is invariably a source of fuel and sustenance to resentment that politicians can use to build their campaigns; a narcotic that makes it possible for hardships experienced by others to fester, spread and become more severe. The crisis of human connection obstructs empathy and blocks the emergence of creative solutions, or even consideration of serious responses to problems large and small.

\section{Public schools and america's response to undocumented children}

Challenges related to the empathy gap and the "crisis of connection" are playing out in many schools throughout the United States today. Unlike other institutions, public schools have historically been required by law to serve all children. ${ }^{2}$ Historically, this has included the undocumented and the children of refugees. ${ }^{2}$ While some of the receiving schools have reacted with hostility and resentment, others have responded with humanity and care. More often than not, they respond without guidance or adequate resources to address the needs of the newly arrived, and for that reason it is not surprising that they often struggle.

In the pages ahead, I analyze some of the struggles that are playing out in schools throughout the US today as they attempt to address the needs of some of our most vulnerable children - unaccompanied minors and undocumented youth generally. I do so in an attempt to ascertain what they tell us about the potential for modern society to move beyond the empathy gap and reduce the crisis of connection. James Banks has described the inadequacy of the state's response to the arrival of refugees as a formed of "failed citizenship". ${ }^{3}$ The failure he points out lies not with the immigrants but with the inability of the modern state to enact policies and procedures to integrate them into

${ }^{1}$ See: Agiesta, Jennifer "Partisan Gap Widens as Demographics Shift" (CNN Polling Director) in CNN Politics, September 16, 2016. p. 1.

${ }^{2}$ In 1982 the US Supreme Court ruled in Plyler V. Doe that states cannot constitutionally deny immigrant students, including the undocumented, free public education. See: "Public Education for Immigrant Students: Understanding Plyler V. Doe" American Immigration Council, October 24, 2012 the new societies where they reside. If American society is to adopt a more humane approach to immigrants and refugees schools will be at the forefront of figuring out how to do so. The examples I present in the pages ahead illustrate what we might expect and hope for if the crisis of connection is addressed and the empathy gap is closed.

\section{From alienation and fear to trust and empathy}

French sociologist Emile Durkheim documented the crisis of connection and its presence in Western society more than two hundred years ago in his seminal work Suicide. ${ }^{4}$ Through an empirical study of suicide in mid nineteenth century France and Germany, Durkheim discovered interesting and unmistakable patterns: those who were most socially isolated were more likely than others to commit suicide. What is most remarkable about Durkheim's finding is that wealth and status do not reduce the likelihood of suicide; rather, they increase the possibility of its occurrence. Durkheim found that wealthy, single, protestant men were more likely to commit suicide than married, working class, Catholic or Jewish women. He found that vulnerability to suicide increased with alienation and isolation, and that the correlates of success: income, education and status, were actually factors that contributed to risk. While his work did not produce clarity related to the causes of suicide, he posited that pervasive alienation and anomie that accompanied industrialization, urbanization, secularization of Western society, were responsible for the increase in self-inflicted deaths.

More than 150 years later, sociologist Eric Klinenberg ${ }^{5}$ identified patterns in the way humans respond to crises that corresponded strikingly to those of Durkheim. Studying mortality patterns in the aftermath of a devastating heat wave in Chicago in July of 1995, Klinenberg ${ }^{5}$ discovered a pattern that was quite revealing: while the elderly were generally more likely to die from the effects of extreme heat than others, their likelihood of dying was substantially greater if they lived alone or resided in a building where they were isolated from other residents. Klinenberg ${ }^{5}$ learned that it was actually not the heat that killed people but the lack of support from others and various forms of social disintegration (anomie)- including the institutional abandonment of poor neighborhoods, and the retrenchment of public assistance programs-that contributed to the high fatality rates.

Klinenberg's research reinforced a finding that social scientists have been aware of for some time now: people need people. Put differently, individuals who are rich in social capital - the resources and benefits one derives from participation in social networks. ${ }^{6,7}$ receive tangible benefits that are often not available to those who lack social capital. These benefits can include access to information, jobs, housing, safety, social support and other forms of material assistance. When individuals are embedded within social networks they generate and benefit from bonds of reciprocity with others who participate in the network. For example, a neighborhood watch group may provide enhanced security to its members simply by watching each others' homes; parent groups provide access to valuable information about babysitters and schools; religious and civic organizations provide members with access to jobs, and information about housing, healthcare and a wide variety of other resources and services. Political scientist Robert Putnam ${ }^{8}$ has argued that when these ties whither and when people become more isolated, the social fabric that holds society together literally begins to fall apart.

In his most recent book, Our Kids, Putnam ${ }^{9}$ argues that growing inequality, the shrinking of the American middle class, and the loss of 
secure, union jobs, has imperiled what is commonly thought of as the American Dream: the possibility that America can be a land where hard work and talent is rewarded with opportunity and social mobility. Putnam reflects on the state of his hometown - Clinton, Ohio, a small, blue-collar city that once managed to send $80 \%$ of its children to college when he graduated in 1964 . Today, the same town bears all the marks of race/class segregation, deindustrialization and capital flight. Most of its residents are trapped in a perpetual cycle of poverty and downward mobility, ravaged by the effects of growing inequality. Only those with means, particularly those with high incomes who live in large homes along the shores of Lake Erie, consistently send their children to college today.

What went wrong? Can it be reversed? As hostility toward immigrants in the US has increased, a growing number of activists and advocates are asking: must we accept a society where suffering and despair are dismissed as foreign problems, where widespread hopelessness festers, and where large numbers of immigrants live in fear of deportation? For educators who are on the frontlines of the refugee crisis in many communities, the critical question is: can public schools become centers of support and beacons of hope for refugees and the undocumented despite growing fear and hostility?

\section{Responding to the needs ofimmigrant children by overcoming the crisis of connection}

As we contemplate how to address the global refugee crisis and consider what it might take to move beyond the fear and xenophobia that has been generated in response, it is important to consider how and why the empathy gap has become an impediment to the development of innovative responses to the needs of immigrant children and what might be done to overcome it. By focusing on the crisis of connection it does not mean that we ignore the substantive challenges faced by undocumented people or refugees - poverty, trauma, lack of adequate housing, and enormous legal challenges, to name just a few. To do so would be naïve and unrealistic. However, it might be possible to devise creative responses if we were to focus on actions that can be taken locally, particularly in schools, involving those most directly affected.

Since 1990, the United States has experienced the greatest influx of immigrants in its history, surpassing even the unparalleled increase in immigration that occurred during the years $-1900-1910 .{ }^{10}$ With a steady increase in the number of immigrants over the last decade, ${ }^{11}$ and a recent crisis triggered by a sudden rise in the number of unaccompanied minors arriving at the border from Central America, ${ }^{12}$ the US has been in the throes of a tumultuous conflict over how to respond to the current influx. The nation's total immigrant population reached a record 40 million or $12.9 \%$ of the US population in $2010,{ }^{10}$ and it is estimated that as much as $30 \%$ of the total immigrant population is comprised of undocumented immigrants..$^{13}$

Public schools in communities experiencing dramatic increases in immigrant populations are confronted with the enormous challenge of figuring out how to respond to their needs. For the most part, schools have received relatively little guidance from the federal or state government in how to handle the task of integrating and educating immigrant children. Reports from schools and data collected on the performance of immigrant children indicate that many schools lack the expertise and resources needed to address their learning needs. In many school districts recent immigrant students have the highest dropout rates and lowest rates of high school graduation and college attendance. ${ }^{14}$ They are also frequently overrepresented in special education, often due to a tendency in many districts to misdiagnose challenges in language acquisition as a form of disability. ${ }^{15}$

In some communities, the political backlash against the growing presence of immigrants has negatively influenced how local schools have responded to the needs of immigrant children. ${ }^{16}$ Despite the large number of Americans with immigrant origins, overt hostility toward newcomers has been a regular occurrence throughout US history. ${ }^{17}$ In recent years, the political backlash against the influx of new immigrants has led to the enactment local and state ordinances in states such as Georgia, Arizona and Pennsylvania, aimed at making it more difficult for undocumented immigrants to work, drive a car, obtain health services or even rent a home have been adopted..$^{18}$

Immigrant youth often face a number of challenges that are directly related to their adjustment to life in the US that place them at greater risk of experiencing negative life outcomes. The challenges are particularly acute for Mexican and Central American youth, whose families are typically poor, have low levels of education, work in low wage (and often dangerous) jobs, and are more likely to be undocumented. ${ }^{19,20}$ Some of these include: stress related to acculturation and social adjustment, ${ }^{11}$ and instability caused by difficulty in maintaining ties with family members abroad. ${ }^{21}$ Existing research suggests that when these risks are not addressed immigrant students often experience a heightened degree of vulnerability to negative social, psychological and educational outcomes. ${ }^{11,14,22-24}$

In many schools that serve recent immigrants, a student's inability to speak English with fluency, or more precisely to display a command over academic literacy, is used as a justification for segregating them from their English-dominant peers and placing them in courses designated for English Language Learners (ELLs) ${ }^{3}$. While such placements are frequently rationalized as a way to ensure that recent immigrant students learn English in a "sheltered" environment, often, classes designated for students who speak English as a Second Language (ESL) are not staffed by qualified teachers, and courses designated to help ELLs often serve as a means through which immigrant students are tracked and marginalized. ${ }^{25,26}$ In many school districts, large numbers of immigrant children fail to acquire proficiency in English, and in many cases, lose proficiency in their native language as well. ${ }^{27}$ Once a student is enrolled in ESL courses they frequently are unable to access the courses needed to fulfill the requirements for college. .5,28,29 $^{25}$ Tracking on the basis of language difference is one of the factors that have been cited by researchers as contributing to the high dropout rates that are common among recent immigrant students. ${ }^{27}$

In many cases, immigrant parents, especially the undocumented, are unaware of how to serve as effective advocates for their children. Accustomed to trusting the educators and schools their children attended in their native country, and lacking the language skills and social capital to navigate schools and the legal barriers that often obstruct access to services, many are unable to effectively advocate for the needs of their children. ${ }^{30,31}$ Additionally, immigrant children often acculturate more quickly than their parents, and frequently acquire skills in English and become familiar with the rules and customs of the new society at a pace that exceeds them. When this happens an imbalance in the relationship between parent and child often occurs as the child assumes the responsibility of translator and negotiator with landlords, service providers and the school system. ${ }^{16,32,33}$

${ }^{3}$ It is important to note that not all recent immigrants are English language learners and not all ELLs are recent immigrants. 
In the final pages of this paper, I utilize three case studies to demonstrate how some schools have responded creatively to the educational needs of immigrant youth and overcome the political hostility and indifference that often characterizes the way they are treated elsewhere. In such schools and communities, confronting the crisis of connection by developing trust and a sense of community has been central to the effort to improve academic outcomes. I use these cases in the hope that by drawing attention to the approach they have taken other schools and communities might feel inspired and compelled to take similar actions.

\section{Case I: Overcoming violence by advancing common interests}

In the fall of 1998, several schools in the San Francisco Bay Area experienced a series of incidents involving interracial violence. The violence involved different groups at different schools, but in each case, immigrant youth were targeted and victimized. At Castlemont (Oakland) and Richmond High Schools the conflicts were between Blacks and Latinos (mostly Central Americans). At Skyline High School (Oakland) the primary conflicts occurred between Blacks and Asians (largely recent immigrants from Southeast Asia). And at El Cerrito and Berkeley high schools various groups (White, Black, Latino and Asian) were fighting each other. There seemed to be no consistent or single cause linking the violence across the five schools, but the violence was occurring frequently and seemed to be spiraling out of control. On numerous occasions, dozens of police officers were deployed to the schools to quell what the police described as "riots" involving large numbers of students. To make matters worse for the local police, these incidents were occurring during roughly the same time period.

The police complained to district officials in all three communities that it was not their job to stop the violence and they made it clear that they could not station police officers indefinitely at the schools. District officials were at a loss for what to do. They didn't understand what was causing the outbreak of violence and had no idea of what they should do to prevent further violence. After a third week of fighting two of the districts approached a community-based research firm - Arts, Resources and Curriculum (ARC), for help in devising a strategy to respond to the violence. The firm came up with a novel idea: they would create multi-racial student-run groups called Youth Together (YT) on each of the five campuses so that students could take the lead in addressing the issue. I was asked to serve as the evaluator of their efforts.

In approaching their work, Youth Together devised a novel strategy. Rather than bringing young people together to talk about the conflicts that had occurred, they started out by bringing a multiracial group of students together to talk about their experiences at schools. The conversation quickly opened up a number of serious complaints about the condition of their schools and within a short period of time, students on each of the five campuses began to see that in their complaints they had a great deal in common. YT decided that rather than simply air their concerns the students should develop school change campaigns, and organize with others to carry them out. The campaigns varied in focus and were devised by the students based on their perception of which issues were of greatest concern. At Richmond and El Cerrito high schools, students signed petitions and marched to the school board to demand access to bathrooms (Bathrooms were locked while classes were in session due to concerns about safety). At Berkeley and Skyline high schools students made demands for ethnic studies classes to be created. At Castlemont High School, Black and Latino students marched together to demand that a new cafeteria be built (for over two years the students had been eating outdoors, even in the rain).

Our research team documented the YT efforts and evaluated the impact of their school change efforts on each the schools. We did this by surveying administrators, teachers and students to assess how the climate of each school was affected by the change campaigns. Remarkably, not only did the violence subside within a short period of time (six - eight weeks) but the surveys revealed that perceptions of safety and the morale of students and staff at each of the schools improved. The following quote from a student at Richmond High School helps to explain the dramatic turnaround:

Most of the fights were caused by stuff that happened outside of school and crept in. Because we didn't even know each other we didn't trust each other. When Youth Together brought us together we started to see that we had a lot in common. As we began working together to get access to the bathrooms we began to see that we were fighting over nothing. We had more in common than we realized. (November 15, 1998)

Similar responses were expressed at the other schools. One teacher at Berkeley High School acknowledged that adults had unintentionally helped to create a climate where violence was likely because they had done so little to bring students together.

We like to celebrate the diversity of this school but actually it's very segregated from within. Our classes are tracked and even the clubs and sports teams are mostly segregated. Our ESL students don't even attend classes with other kids. How can we expect kids to learn how to respect each when they aren't learning together?

Our study found that by getting students to work together to improve their schools and promote their common interests, the schools not only experienced a reduction in hostility, conflict and fear, students from different racial backgrounds also began to forge bonds based on solidarity and trust. ${ }^{34}$ Such relationships are especially important for the recent immigrant students who have a limited understanding of race and racism in America, and who are often marginalized and segregated within schools. By working with classmates they once feared or regarded as a threat, and by engaging in efforts to improve the quality of their schools, the immigrant students not only experienced a reduction in violence, they also became more integrated into their schools.

It is important to note that to even consider these types of solutions to racial conflict the schools had to cease relying exclusively on security measures to address the conflict. They had to take what some might regard as a tremendous risk: listening to the perspectives of students. Recognition that listening to students can be helpful to schools compels those in leadership to see students as legitimate partners in the educational process. As we will see in the following case, such recognition can be of enormous benefit to schools.

\section{Case 2: Listening to students for school improvement}

In 2001, I was approached by the former superintendent of Boston, Dr. Tom Paizant, about helping him to figure out how to improve several of the high schools in the school district. Like most urban school districts across the country, Boston had experimented with a 
number of reforms in an attempt to raise achievement at its' schools. Many of the most troubled schools served recent immigrants who struggled with academic English. With the newly devised MCAS (Massachusetts Comprehensive Assessment for Students - a high stakes examination that all $10^{\text {th }}$ graders were required to take), Paizant was looking for ways to help his schools improve. Under his leadership a number of different reforms had been implemented at each of the high schools but after several years of effort it was clear that while some schools were improving several others were not.

Paizant wanted to know why progress was uneven at the schools in the district and what could be done about it. After visiting several of the schools in the district with him I proposed what he and I considered a novel idea: we would study the impact of the reforms through the experience of the students. We opted for this focus because we wanted to know whether students were experiencing the benefits that were intended by particular reforms. I proposed that we could do this by shadowing 15 students at ten different high schools. The groups would be representative of the schools with respect to race, ethnicity, immigration status and gender, and would include students with differing levels of academic achievement -5 low, 5 medium, and 5 high.

While the project was not designed with an explicit focus on immigrant students, all ten of the schools served large immigrant populations, from Latin America, Asia and Africa. Over the course of the next two years we followed our focal students to their classes, interviewed them, their teachers and their parents periodically, and tracked their academic performance. We also collected school climate surveys, which allowed us to compare the responses of our focal students to the larger population of students at each school. Specifically, we wanted to know: Did students report that they had developed closer, more supportive relationships with teachers, as their schools were re-structured and made smaller? Did they receive better and more rigorous instruction as their schools prepared for high stakes exams? Did students who struggled academically receive sufficient support? Did charter schools or pilot schools have greater success in meeting the needs of students than traditional public high schools, and if so, why? For the immigrant students, who represented over half of the sample, we were particularly interested in knowing how effectively the schools were meeting their academic needs since most were at highest risk of failing the state exam.

The questions we posed were central to the larger policy debates that were occurring throughout the country related to education reform. However, largely missing from these debates was the voices of students. There seemed to be an unstated assumption that if the adults got the reforms right students would eventually achieve at higher levels. Our research at the schools allowed us to test the theories underlying the reform strategies. It also allowed us to elevate the voices of students so that their perspectives and experiences were considered, in many cases, for the first time.

Over the course of two years we began to see significant discrepancies at several of the schools between what the adults claimed they were doing and what the students were actually experiencing. We went into classrooms serving students who had failed the state exam and were at risk of being denied diplomas if they did not eventually pass. Expecting to see rigorous, highly focused instruction, more often than not we saw disorganized teachers, who were often unprepared to meet the needs of the students they served. For example, during one visit to a math class a Honduran student we had been following informed us that he and his classmates usually played poker during class, but he suspected that because we were present, the teacher might make them do some work. Despite our presence, the students played poker anyway. Embarrassed by the obvious lack of educational focus, the teacher turned to us and said: "These kids refuse to do any work so I let them play. They're probably learning more math playing poker than they would from my lesson anyway."

Observations of this kind were not uncommon at several of the schools. We observed students who were supposed to be preparing for high stakes exams chatting, brushing their hair and putting on makeup in class. At one school I saw the principal lock the front door to the school at 7:35am, denying entry to students who arrived more than five minutes late (7:30am was the official time school was supposed to start) until they could return with a note from a parent or an adult explaining their tardiness. I pointed out sarcastically that his tough tardy policy had created a truancy problem, but he failed to note the irony of my observation.

At other schools we pointed out that many of the students lacked basic skills in literacy and math and were unlikely to pass the state's new high stakes exam if the classes they took only focused on providing test-taking skills. This was particularly the case for recent immigrants who were still acquiring academic English fluency. However, even after sharing our findings with the schools, the disconnect between what the adults asserted they were doing in the name of reform with what the students actually experienced (and needed), remained, and despite our efforts to point out these contradictions the issues were unaddressed.

However, we also visited schools where relationships between students and teachers were strong, where immigrant students and English language learners received high quality academic support and were able to clearly explain what they were learning in their classes and why it was important. What set these schools apart from the others appeared to be coherence in the organizational plan and the school's culture. Several researchers have found that when schools are organized around a clear mission, when they adopt strategies to ensure that the skills of professional staff match the learning address of students, and when the beliefs, expectations, values and norms are aligned with its mission and purpose, schools are more likely to be successful. ${ }^{35-38}$ We learned that at such schools, students took their education seriously, both in word and in deed, not because they were afraid of failure but because they were fully integrated into the life of the school and they accepted the premise upon which the school operated.

In contrast with students at the dysfunctional schools, students in the higher functioning schools also accepted responsibility for their education and did their part to maintain a safe, orderly environment. In a more detailed discussion of the findings,${ }^{39,40}$ I describe how the strong, positive relationships we observed contributed to higher levels of school safety and student achievement. What is most important about these findings is that they run counter to official policies designed to promote school safety and higher achievement. Current education policies designed to promote safety generally emphasize the adoption of strict security measures including: metal detectors, law enforcement, surveillance cameras and zero tolerance policies. ${ }^{41}$ Similarly, the policy lever used to promote increased student achievement has in recent years consisted almost exclusively of 
high stakes testing and the elevation of academic standards. ${ }^{42,43}$ Our research at ten Boston high schools showed that the development of strong, positive relationships between teachers and students was more effective than heavy security measures in creating a safe and orderly environment. We also found that hope was more effective than fear in motivating students to achieve.

It is important to note that while positive relationships and a student-centered culture cannot be imposed upon a school, a coherent strategy for meeting student needs can be implemented when all stakeholders - teachers, students and parents, are organized around a common vision. Research on school improvement ${ }^{37}$ has shown that when schools clearly define their problems and adopt research-based strategies to address them, they can experience steady, incremental improvement. This is what occurred at Brockton High School, an urban school with a large immigrant population that is now widely regarded as a success story, ${ }^{44}$ and at several of the schools in our study.

While it me be easier to install a metal detector or surveillance cameras to address safety concerns than to work on improving the quality of relationships between children and the adults that serve them, the long term benefits of the latter far outweigh the short-term relief provided by the former. However, if we fail to recognize that such "non-technical" approaches might actually work to create trust and bridge the empathy gaps, and be more effective in realizing the goals of education, chances are they will never even be considered.

\section{Not giving into fear:Acting on our common interests}

In bringing this paper to conclusion I want to end with a story conveyed to me by a teacher from a school, that illustrates the power of trust, community and the need for the courage to act on our common interests. I share this because it serves as an excellent example of how we can overcome our fears through positive action that affirms the basic human values that are essential for living in a just, civil society.

The school in question was a small continuation high school, ${ }^{4}$ designed to serve students with a record of poor attendance, poor behavior, or both. Many of the students at the school had criminal records, and most had a long record of poor academic performance. One of the students at the school, a well-known gang leader from El Salvador with a reputation for violence in the community, informed his counselor one morning that starting tomorrow he was going to show up at a school with a new identity - he was going to be a young woman. She explained that she intended to change her name from Carlos to Carla, that she would dress as a woman, and wanted her choice to be respected. She informed the counselor that her parents had kicked her out the house because they were unhappy with her new transgender identity. She also warned the counselor that she expected a violent reaction to news of her transformation by members of her own gang, who felt betrayed by her decision.

The counselor reacted with alarm due to the likelihood of violence and immediately notified the school principal. The principal was equally alarmed by the possibility that there might be an outbreak of gang violence at his school, so at the end of the day he called for a meeting with the faculty and staff to warn them and figure out what should be done. Fearful of the violence they thought might occur, the staff immediately decided that the police should be notified and the student should be banned from entering the school. However, while the adults were in the middle of their meeting a small delegation of

${ }^{4}$ Continuation high schools are alternative schools that are designed to serve students with a track record of poor attendance and poor academic performance. students arrived and asked for an opportunity to speak. They wanted the staff to know that they were aware of their classmate's decision to change her gender identity, and on their own, they had devised a plan to support her. Since Carla had been kicked out of her parent's home she would start living with another student at the school that was willing to take her in. The students also reported that they had organized themselves to take turns riding the bus with Carla to school each day to provide protection. Finally, they agreed that while she was in school everyone would accept and respect her decision, and begin calling her by her preferred name and pronoun.

The school staff was shocked by the news shared by the students. Several spoke up and said how proud they were that the students had come together to support their classmate. One admitted how embarrassed she was because of the actions she and her colleagues had proposed - calling the police and banning the student, prior to hearing from the students. After further deliberation that staff decided that they would support the students' approach, and that together they would support the transgendered student. The following day the plan was implemented as proposed. No violence occurred, and ultimately, Carla was able to complete the school year and graduate without any violent incidents occurring at the school.

\section{Conclusion}

I share this final story because it serves as a poignant way of reinforcing the larger point of this paper. While the crisis of connection is real, rooted in history, and reinforced by divisions that have led to deep distrust and disconnection based on race, language, sexuality, gender, nationality, etc., the examples cited show that it might be possible for the crisis of connection to be overcome, at least in schools. Even for refugees and undocumented immigrants who are increasingly vilified, scorned and denied access to basic human rights, schools can become centers of support and refuges where they can escape persecution and threats. The examples cited show that listening to students, developing caring relationships, and even countering racial violence by focusing on the common interest of students, can all help to create schools where compassion is the norm and even the most vulnerable feel safe. Such examples remind us that it is possible to counter fear with empathy, and that possibilities for addressing complex problems may be more likely if we focus directly on addressing the crisis of connection. While these examples don't serve as proof that it will be easy to solve the global refugee crisis, it does suggest that creative strategies that focus on overcoming the empathy gap must be considered if we are to address the large complex problems we face.

In the last few months we have been inundated by news of mass drowning's as boats carrying refugees capsize in the Mediterranean, of borders closing due to fears pertaining to terrorists attacks, and of mass arrests by immigration agents targeting the undocumented. Such incidents are occurring in communities throughout the US (including so-called sanctuary cities), and in a diverse array of countries throughout the world. The news is frightening and the problem may seem overwhelming. Because the atrocities occur with such frequency, they can easily become accepted as the new normal. But why should we accept it? Normalization and complacency toward human suffering must be seen for what they are: threats to our collective future that can and must be resisted through creative forms of action. What we need is actions and strategies that assert our common interests as human beings, and that further and promote empathy, trust and goodwill. 
The renown French geophysicist, Xavier Le Pichon, reminds us that: "Our humanity is not an attribute that we have received once and forever with our conception. It is a potentiality that we have to discover within us and progressively develop or destroy through our confrontation with the different experiences of suffering that will meet us throughout our life." 45

Like Le Pichon, I am under no illusion that the problems we face can be solved by simple solutions or small acts of kindness. However, I do believe that the best way to counter indifference and resentment, and the most effective way to revive a pragmatic form of optimism about the future of the planet and human society, is through deliberate actions that address our crisis of connection, and that remind us that our common interests as human beings are worth acting upon.

\section{Acknowledgments}

None.

\section{Conflicts of interest}

The author declares no conflicts of interest.

\section{Funding}

None.

\section{References}

1. UNHCR. Figures at a Glance. Global Trends, statistical yearbooks. 2015 .

2. Fass P. Outside in: Minorities and the Transformation of American Education. New York: Oxford University Press; 1991:308.

3. Banks. Failed citizenship and transformative civic education. Educational Researcher. 2017;20(10):1-12.

4. Durkheim Emile. Suicide: a study in sociology. The Free Press; 1951.

5. Klinenberg E. Heat Wave: A Social Autopsy of Disaster in Chicago Chicago: University of Chicago Press; 2002.

6. Coleman J. Social capital in the creation of human capital. American Journal of Sociology. 1988;94 (supp):S95-S120.

7. Woolcock M. Social Capital and Economic Development: Toward a Theoretical Synthesis and Policy Framework. Theory and Society. 1998;27(2):151-208.

8. Putnam R. Bowling Alone. New York: Simon and Schuster; 2000.

9. Putnam R. Our Kids. The American Dream in Crisis. New York: Simon and Schuster; 2015.

10. Grieco E, E Trevelyan, L Larsen, et al. The Size, Place of Birth, and Geographic Distribution of the Foreign-Born Population in the United States: 1960 to 2010. Population Division Working Paper No. 96. Washington, D.C.: U.S. Census Bureau. 2012.

11. Suarez-Orozco C, M Suarez-Orozco, I Todorova. Learning A New Land: Immigrant Students in American Society. Perspectives on urban education. 2009:83.

12. Park H. Children at the Border. The New York Times. 2017.

13. Passel J, D Cohn. U.S. Population Projections: 2005 - 2050. Pew Research Center: Washington DC; 2013.

14. Rodriguez L. The Time Is Now. New York: Peter Lang. 2014.

15. Figueroa R. Dificultades o Desabilidades de Aprendizaje?. Learning Disability Quarterly. 2005;28(2):163-167.

16. Olsen Laurie. Made in America: Immigrant Students in Our Public Schools. New York City: The New Press; 1997.
17. Roediger D. The wages of whiteness. New York: Verso Press; 1991.

18. Yoshikawa H. Immigrants Raising Citizens: Undocumented Parents and Their Young Children. New York: Russell Sage; 2011.

19. Suárez-Orozco C, Suárez-Orozco M. Children of immigration. Cambridge, MA: Harvard University Press; 2002.

20. Smith Robert. Mexican New York: Transnational Lives of New Immigrants. Berkeley, CA: University of California Press; 2006.

21. Bartlett L, García O. Additive schooling in subtractive times: Bilingual education and Dominican immigrant youth in the Heights. Nashville, TN: Vanderbilt University Press; 2011.

22. Thom L. Immigration's Impact on Teen Pregnancy and Juvenile Crime. Population and Environment. New York: Springer, 1998;18(5).

23. Perreira K, I Ornelas. Physical and Psychological Well-Being In Immigrant Children. Future Child. 2011;21(1):195-218.

24. Conchas GQ, Vigil JD. Multiple marginality and urban education: Community and school socialization among low-income Mexicandescent youth. Journal of Education for Students Placed at Risk. 2010;15(1-2):51-65.

25. Noguera P, J Wing. Unfinished Business: Closing the Achievement Gap in Our Nation's Schools. San Francisco: Josey Bass; 2006.

26. Kao G, E Vaquera, K Goyette. Education and Immigration. Cambridge, MA: Polity Press; 2013.

27. Gandara P, Rumberger R. Immigration, language, and education: How does language policy structure opportunity. The Teachers College Record. 2009;11(3):750-782.

28. Gandara PC, Contreras F. The Latino education crisis: The consequences of failed social policies. Cambridge, MA: Harvard University Press; 2009.

29. Stanton-Salazar RD. Manufacturing hope and despair: The school and kin support networks of US-Mexican youth. New York: Teachers College Press; 2001.

30. Garcia Coll C, Akiba D, Palacios N, et al. Parental involvement in children's education: Lessons from three immigrant groups. Parenting: Science and Practice. 2002;2(3):303-324.

31. Kasinitz P, Mollenkpf JH, Waters MC, et al. Inheriting the City: The children of immigrants come of age. New York: Russell Sage; 2008.

32. Orellana MF. Translating Childhoods: Immigrant Youth, Language, and Culture. New Brunswick, NJ: Rutgers University Press; 2009.

33. Giguère $B$, Lalonde R, Lou E. Living at the crossroads of cultural worlds: The experience of normative conflicts by second-generation immigrant youth. Social and Personality Psychology Compass. 2010;4(1):14-29.

34. Noguera PA, Bliss M. School violence reduction initiative: Youth Together Project. Final year Report. Berkeley, CA: Center on Diversity \& Urban School Reform, University of California. Berkeley, December 1998; 2001.

35. Sarason S. The Culture of Schools and the Problem of Change. Boston: Allyn and Bacon; 1971.

36. Gregory A, R Skiba, P Noguera. Closing the Discipline Gap. In Review of Educational Research, January; 2010.

37. Bryk A, LM Gomez, A Grunow, et al. Learning to Improve: How America's Schools Can Better at Getting Better. Cambridge, MA: Harvard Education Press; 2015.

38. Fullan Michael. Choosing the Wrong Drivers for Whole System Reform. Centre for Strategic Education Seminar Series Paper No. 204; 2011.

39. Noguera PA. Transforming High Schools. Educational Leadership. 2004;61(8).

40. Noguera P. How Listening to Students Can Help Schools to Improve. Theory Into Practice. 2007;46. 
41. Gottfredson D. Schools and delinquency. Cambridge: Cambridge University Press; 2001.

42. Elmore R. The new accountability in state educational policy. In: H Ladd, editor. Performance Based Strategies for Improving Schools. 1996.

43. Darling-Hammond L. Standards, accountability, and school reform. Teachers College Record, 2004;106:1047-1085.
44. Bryk A, LM Gomez, A Grunow, et al. Learning to Improve: How America's Schools Can Better at Getting Better. Cambridge, MA: Harvard Education Press; 2015.

45. Blankstein Alan, P Noguera. Excellence Through Equity. Washington, DC: ASCD; 2015.

46. Le Pichon Xavier. ECCE Homo - "Behold Humanity" Paris: Templeton Foundation; 2012. 